\title{
Review
}

\section{Formation and Evolution of Inclusions in High Chromium Steel}

\author{
Yoshihiko Higuchi ${ }^{1 *}$, Hideki $\mathrm{ONO}^{2)}$ and Katsuyoshi Окимото ${ }^{3)}$ \\ 1) Department of Mechanical Engineering, College of Industrial Technology \\ 2) Academic Assembly, Faculty of Sustainable Design, University of Toyama \\ 3) Graduate School of Science and Engineering for Education, University of Toyama, now Daido Steel Co., Ltd.
}

Abstract: Controlling inclusion content in high chromium steel is very important to prevent submerged entry nozzle from clogging in continuous casting and avoid the negative impacts of inclusions on steel properties. Therefore, effects of temperature and content of elements on phase stability diagram should be clarified in chromium bearing steel. However, the effect of chromium content on boundaries of $\mathrm{MgO}, \mathrm{MgO} \cdot \mathrm{Al}_{2} \mathrm{O}_{3}$ and $\mathrm{Al}_{2} \mathrm{O}_{3}$ in phase stability diagram are much different among the researchers. The direction of boundaries shift is affected by chromium content differently. Temperature dependencies of deoxidation equilibrium constants below $1873 \mathrm{~K}$ are also scattered. Calcium, which is used to avoid the negative effect of $\mathrm{MgO} \cdot \mathrm{Al}_{2} \mathrm{O}_{3}$ inclusion, enlarges liquid region in phase stability diagram. However, the region replaced by liquid oxide is understood differently in low alloyed steel and high chromium steel. In $\mathrm{TiO}_{\mathrm{x}}-\mathrm{Al}_{2} \mathrm{O}_{3}$ $\mathrm{MgO}$ system inclusion, commercial thermochemical software predicts that boundaries of $\mathrm{Ti}_{2} \mathrm{O}_{3}, \mathrm{Ti}_{3} \mathrm{O}_{5}$, $\mathrm{Al}_{2} \mathrm{O}_{3}$ and $\mathrm{TiO}_{\mathrm{x}}-\mathrm{Al}_{2} \mathrm{O}_{3}$ shift toward lower titanium content in high chromium steel. However, the calculated phase stability diagrams vary among studies even in liquid iron or low alloyed steel. Therefore, equilibrium experiments under various conditions and reliable technique of thermodynamic calculation with high accuracy are desired.

Keywords: inclusion; slag; spinel inclusion; $\mathrm{CaO}-$ $\mathrm{MgO}-\mathrm{Al}_{2} \mathrm{O}_{3}$ system; $\mathrm{TiO}_{\mathrm{x}}-\mathrm{Al}_{2} \mathrm{O}_{3}-\mathrm{MgO}$ system; stainless steel; deoxidation.

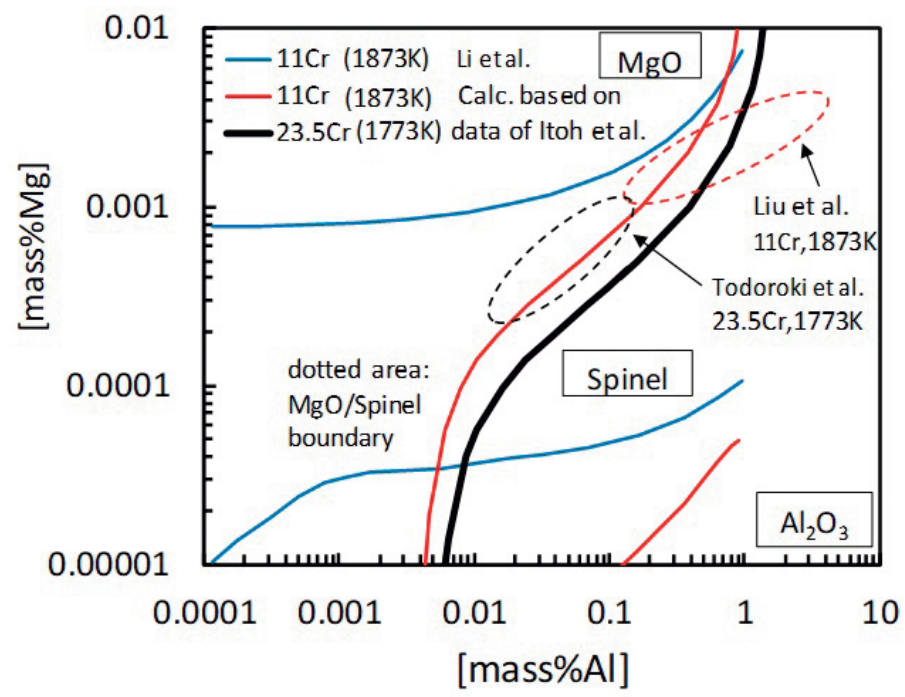

Received on Dec. 5, 2021; Accepted on Jan. 25, 2022; J-STAGE Advance published on Mar. 4, 2022; originally published in ISIJ Int., Vol.61, 2021, No.9, pp.2324-2330

* Corresponding author. E-mail: higuchi@cit.sangitan.ac.jp, Address: College of Industrial Technology, 1-27-1 Nishikoya Amagasaki Hyogo 


\title{
高クロム鋼中の介在物の生成と組成変化
}

\author{
樋口 善彦 ${ }^{1) *}$ ・ 小野 英樹 ${ }^{2)} \cdot$ 奥本 括嘉 ${ }^{3)}$
}

Formation and Evolution of Inclusions in High Chromium Steel

Yoshihiko Higuchi, Hideki Ono and Katsuyoshi Окимото

\section{1. 緒言}

高クロム鋼中の $\mathrm{MgO} \cdot \mathrm{Al}_{2} \mathrm{O}_{3}$ スピネル介在物は表面性状 および成形性や而疲労特性などの機械特性に悪影響を与 えることが知られている。その欠点は本質的に高融点と高 硬度に由来する。工場の操業における精錬から鋳造までの 工程では他の問題もある。 $\mathrm{MgO} \cdot \mathrm{Al}_{2} \mathrm{O}_{3}$ スピネル介在物は 鋳造中に浸漬ノズル (SEN: submerged entry nozzle) の内壁 に付着する傾向がある。その結果，ノズル閉塞が生産性を 低下させ，堆積物から剥がれた小片が表面欠陥を引き起 こしてしまう ${ }^{1-4)}$ 。鋳造中の溶融した高クロム鋼の温度は 溶鉄あるいは低合金鋼よりも低い。したがって，1873 Kよ り低い温度, 特に $1773 \mathrm{~K}$, での熱力学データの取得が重要 である。鋼材で見つかる介在物にはAOD (Argon Oxygen Decarburization）または取鍋での処理中に巻き込まれた精 錬スラグを起源とするものがあることが報告されている。 巻き込まれたスラグ粒子中のアルミナ濃度は製造プロセス 中に増加するが，それは取鍋から鋳造にかけて温度が低下 するためである。介在物中のアルミナ濃度の増加は溶鋼中 での $\mathrm{MgO} \cdot \mathrm{Al}_{2} \mathrm{O}_{3}$ 相の晶出を促進する。溶鋼中の $\mathrm{MgO} \cdot \mathrm{Al}_{2} \mathrm{O}_{3}$ の存在は上述したように強い付着性のためにノズル閉塞を 促進する。しかし，多くの研究が高い液相線温度をもつ低 合金鋼を主な対象としてきたため, 高クロム鋼の低温条件 での熱力学データは少ない。

一方，スピネル介在物はデルタフェライトとの良好な格 子整合性を有するチタン窒化物，TiN，の生成を促すこと でチタン含有フェライト系ステンレス鋼の等軸晶の生成を 促進することができる ${ }^{5-7)}$ 。チタンはクロム欠乏層の形成 により粒界腐食を引き起こす固溶炭素や窒素を固定するた めに高クロム鋼に添加される。添加されたチタンの一部は
酸化し, $\mathrm{Ti}_{2} \mathrm{O}_{3}$ や $\mathrm{Ti}_{3} \mathrm{O}_{4}$ などの酸化物を形成する ${ }^{8)}$ 。さらに, アルミキルド鋼の場合には $\mathrm{Al}_{2} \mathrm{O}_{3}-\mathrm{TiO}_{\mathrm{x}}-(\mathrm{MgO})$ 系酸化物が 生成する場合がある ${ }^{9)}$ 。この酸化物はスピネルと同様の理 由で鋼品質を低下させてしまう。

これらの理由から，商業生産における製鋼プロセスでは 介在物組成の制御が極めて重要である。これまでに，溶鉄 や低合金鋼，高クロム鋼を対象にした介在物制御に関する 多くの研究が行われてきた。Park and Todoroki ${ }^{10)}$ はステン レス鋼のスピネル介在物を対象に包括的な解説を行ってい

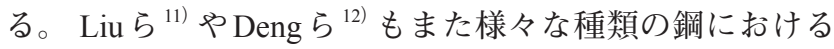
介在物の生成と組成変化を解説している。しかし, 熱力学 計算に関わる報告值間での小さくない相違が存在してい る。特に $\mathrm{MgO} \cdot \mathrm{Al}_{2} \mathrm{O}_{3}$ スピネルや $\mathrm{TiO}_{\mathrm{x}}-\mathrm{Al}_{2} \mathrm{O}_{3}$ 介在物の挙動に 及ぼすクロム濃度の影響は研究者間の差異が大きい。した がって, 操業のための脱酸条件を決定することが困難であ る。本報告は, 熱力学的な評価の差異および介在物制御の ために今後必要とされる研究について議論する。

\section{2. $\mathrm{MgO}-\mathrm{Al}_{2} \mathrm{O}_{3}(-\mathrm{CaO})$ 系介在物}

\section{$2 \cdot 1 \mathrm{MgO}, \mathrm{MgO}-\mathrm{Al}_{2} \mathrm{O}_{3}$ および $\mathrm{Al}_{2} \mathrm{O}_{3}$ 系介在物の相安定図}

Park and Todoroki ${ }^{10)}$ とLi ${ }^{13,14)}$ はそれぞれ，様々なク口

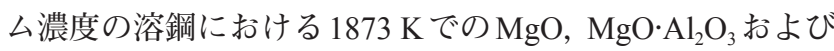
$\mathrm{Al}_{2} \mathrm{O}_{3}$ 系介在物の相安定図を商用の熱化学ソフトウェアと データベース（FactSage）を用いて計算している。それらの 計算結果を比較して Fig.1に示す。この図によれば，アルミ ニウム濃度が $0.003 \mathrm{mass} \%$ 以上の領域では, クロム濃度が 増加すると $\mathrm{MgO} / \mathrm{MgO} \cdot \mathrm{Al}_{2} \mathrm{O}_{3}$ 境界と $\mathrm{MgO} \cdot \mathrm{Al}_{2} \mathrm{O}_{3} / \mathrm{Al}_{2} \mathrm{O}_{3}$ 境界は とともに高マグネシウム濃度側へ移動することがわかる。 その一方で, $\mathrm{MgO} / \mathrm{MgO} \cdot \mathrm{Al}_{2} \mathrm{O}_{3}$ 境界はクロム濃度とアルミニ

原著論文: ISIJ Int., Vol.61 (2021), No.9, pp.2324-2330

2021年12月5日受付 2022年1月25日受理 2022年3月4日J-STAGE早期公開 (Received on Dec. 5, 2021; Accepted on Jan. 25, 2022; J-STAGE Advance published on Mar. 4, 2022; originally published in ISIJ Int., Vol.61, 2021, No.9, pp.2324-2330)

1）産業技術短期大学機械工学科 (Department of Mechanical Engineering, College of Industrial Technology)

2) 富山大学学術研究部都市デザイン学系 (Academic Assembly, Faculty of Sustainable Design, University of Toyama)

3）富山大学大学院理工学教育部 (現: 大同特殊鋼 (株)) (Graduate School of Science and Engineering for Education, University of Toyama, now Daido Steel Co., Ltd.)

* Corresponding author. E-mail: higuchi@cit.sangitan.ac.jp, Address: College of Industrial Technology, 1-27-1 Nishikoya Amagasaki Hyogo 
ウム濃度の影響をさほど受けないことがわかる。アルミニ ウム濃度が 0.003 mass\%以下の領域では, クロム濃度の増 加とともに $\mathrm{MgO} \cdot \mathrm{Al}_{2} \mathrm{O}_{3} / \mathrm{Al}_{2} \mathrm{O}_{3}$ 境界は低マグネシウム濃度側 へ移動している。

先に述べた熱化学ソフトウェアでは, 熱力学モデルと データベースに基づいて計算が行われている。プログラム 内部の計算方法は複雑である。その結果，脱酸反応の平衡 定数および一次や二次の相互作用係数などの様々な要素の 影響の程度を評価することが難しくなっている。この商用 ソフトウェアによる結果と従来の熱力学手法を使って計 算した結果との比較を行った。使用した方法と熱力学パラ

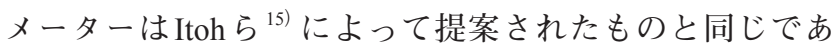
る。ここで扱うのは式 (1)-(3) で示した反応であり，その 脱酸平衡定数は文献值より式 (4)-(6) で与えられる ${ }^{16-18)}$ 。 $\mathrm{MgO}$ 飽和条件での $\mathrm{MgO}$ および $\mathrm{MgO} \cdot \mathrm{Al}_{2} \mathrm{O}_{3}$ の活量は 1 と 0.8 とし, $\mathrm{Al}_{2} \mathrm{O}_{3}$ 飽和条件での $\mathrm{Al}_{2} \mathrm{O}_{3}$ および $\mathrm{MgO} \cdot \mathrm{Al}_{2} \mathrm{O}_{3}$ の活量は 1 と 0.47 にそれぞれ設定した ${ }^{18)}$ 。なお，ク口ム濃度の影響 を考慮するために, 相互作用パラメーターには Table 1 に示 したように $e_{\mathrm{Mg}}^{\mathrm{Cr}}$ および $e_{\mathrm{Al}}^{\mathrm{Cr}}, e_{\mathrm{O}}^{\mathrm{Cr}}$ を加えている。

$$
\operatorname{MgO}(\mathrm{s})=\underline{\mathrm{Mg}}+\underline{\mathrm{O}}
$$

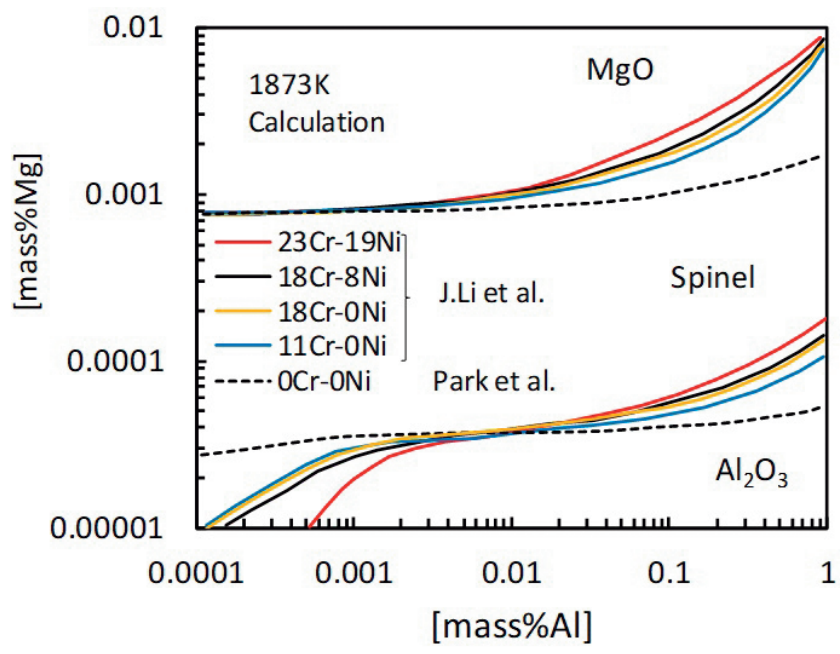

Fig. 1. Phase stability diagram of $\mathrm{MgO}, \mathrm{MgO} \cdot \mathrm{Al}_{2} \mathrm{O}_{3}$ and $\mathrm{Al}_{2} \mathrm{O}_{3}$ inclusions at $1873 \mathrm{~K}$ by Lie et al. and Park et al. (Online version in color.)

Table 1. First and second order interaction parameter, $e_{i}^{j}, r_{i}^{j}$ and $r_{i}^{j, k}$ in molten steel used in this work.

\begin{tabular}{ccccc}
\hline $\mathrm{i}$ & $e_{\mathrm{i}}^{\mathrm{Al}}$ & $e_{\mathrm{i}}^{\mathrm{Mg}}$ & $e_{\mathrm{i}}^{\mathrm{O}}$ & $e_{\mathrm{i}}^{\mathrm{Cr}}$ \\
\hline $\mathrm{Al}$ & $0.043^{19)}$ & $-0.019^{20)}$ & $-1.98^{17)}$ & $0.0096^{21)}$ \\
$\mathrm{Mg}$ & $-0.017^{20)}$ & 0 & $-430^{16)}$ & $0.047^{22)}$ \\
$\mathrm{O}$ & $-1.17^{17)}$ & $-280^{16)}$ & $-0.17^{19)}$ & $-0.032^{23)}$ \\
\hline \multicolumn{5}{c}{$r_{\mathrm{Al}}^{\mathrm{O}}=40^{17)}, r_{\mathrm{Al}}^{\mathrm{Al}, \mathrm{O}}=-0.028^{17)}, r_{\mathrm{Al}}^{\mathrm{Mg}, \mathrm{O}}=-260^{15)}$} \\
\hline \multicolumn{5}{c}{$r_{\mathrm{Mg}}^{\mathrm{O}}=350000^{16)}, r_{\mathrm{Mg}}^{\mathrm{Al}, \mathrm{O}}=-230^{15)}, r_{\mathrm{Mg}}^{\mathrm{Mg}, \mathrm{O}}=-61000^{16)}$} \\
\hline \multicolumn{5}{c}{$\mathrm{Mg}=-20000^{16)}, r_{\mathrm{O}}^{\mathrm{Al}, \mathrm{O}}=47.4^{177}, r_{\mathrm{O}}^{\mathrm{Mg}, \mathrm{O}}=462000^{16)}$} \\
\end{tabular}

$\mathrm{Al}_{2} \mathrm{O}_{3}(\mathrm{~s})=2 \underline{\mathrm{Al}}+3 \underline{\mathrm{O}}$

$\mathrm{MgO}(\mathrm{s}) \cdot \mathrm{Al}_{2} \mathrm{O}_{3}(\mathrm{~s})=\mathrm{Al}_{2} \mathrm{O}_{3}(\mathrm{~s})+\mathrm{MgO}(\mathrm{s})$

$\log K_{\mathrm{MgO}}=\log \frac{a_{\mathrm{Mg}} \cdot a_{\mathrm{O}}}{a_{\mathrm{MgO}}}=-4.280-\frac{4700}{T}$

$\log K_{\mathrm{Al}_{2} \mathrm{O}_{3}}=\log \frac{a_{\mathrm{Al}}^{2} \cdot a_{\mathrm{O}}^{3}}{a_{\mathrm{Al}_{2} \mathrm{O}_{3}}}=11.620-\frac{45300}{T}$

$\log K_{\mathrm{MgO} \cdot \mathrm{Al}_{2} \mathrm{O}_{3}}=\log \frac{a_{\mathrm{MgO}} \cdot a_{\mathrm{Al}_{2} \mathrm{O}_{3}}}{a_{\mathrm{MgO} \cdot \mathrm{Al}_{2} \mathrm{O}_{3}}}=-0.820-\frac{1085}{T}$

Fig.2に示すように, $\mathrm{MgO} / \mathrm{MgO} \cdot \mathrm{Al}_{2} \mathrm{O}_{3}$ 境界および $\mathrm{MgO}$. $\mathrm{Al}_{2} \mathrm{O}_{3} / \mathrm{Al}_{2} \mathrm{O}_{3}$ 境界の計算結果がクロム濃度の増加とともに 低マグネシウム濃度側に移動することがわかる。この移動 方向は相互作用助係数 $e_{\mathrm{Mg}}^{\mathrm{Cr}}(0.047)$ が正の值であることに 起因している。なお，他の研究者によって提案されている $e_{\mathrm{Mg}}^{\mathrm{Cr}}$ も0.01 (Nadif and Gatellier $\left.{ }^{24)}\right)$ および0.022 (Jo ら ${ }^{25)}$ ) で あることから, この相互作用上助係数が正であることは信 頼できる。この Fig. 2 を Fig.1 と比較すると, クロム濃度が 相境界の移動方向に正反対の作用を及ぼしていることから Fig.1の相安定図は再考する必要があることが示唆される。

高クロム鋼を用いた研究には, $\mathrm{MgO} / \mathrm{MgO} \cdot \mathrm{Al}_{2} \mathrm{O}_{3}$ 境界を 特定したものもある。Liu ら ${ }^{26)}$ は $1873 \mathrm{~K} て ゙ 11$ mass\%のクロ 厶を含有した溶鋼で実験室規模の坩堝実験を行っており， Todoroki ら ${ }^{4)}$ は商用生産の連続鋳造において 23.5 mass\%の クロムを含有した溶鋼中の介在物を調査している。これら の結果を破線でFig.3に示す。実験と同じ条件を使った熱 力学計算を行い, その計算結果も同じ困に示す。実験結果 と計算結果を比較すると, $\mathrm{MgO}$ と $\mathrm{MgO} \cdot \mathrm{Al}_{2} \mathrm{O}_{3}$ の相境界の 計算值は実験值に対して, 高アルミニウム濃度域 $(>0.3$

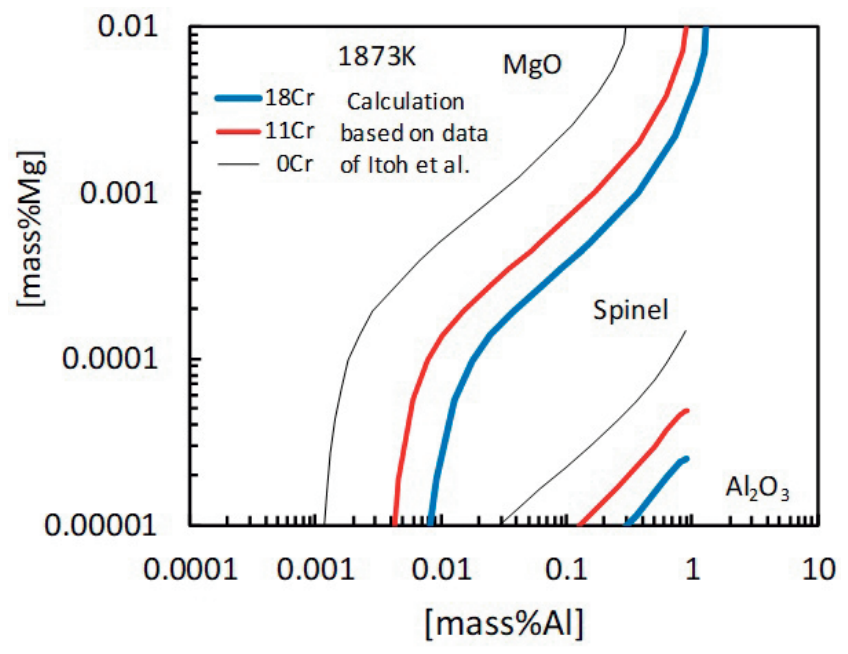

Fig. 2. Phase stability diagram of $\mathrm{MgO}, \mathrm{MgO} \cdot \mathrm{Al}_{2} \mathrm{O}_{3}$ and $\mathrm{Al}_{2} \mathrm{O}_{3}$ inclusions at $1873 \mathrm{~K}$. (Online version in color.) 
mass\%）では高マグネシウム濃度側に, 低アルミニウム濃 度域 $(<0.1$ mass\%) では過度に低いマグネシウム濃度側に 位置していることがわかる。

\section{$2 \cdot 2$ 相安定図に及ぼす平衡定数の影響}

ここでは上述した差異が脱酸平衡定数の組合せを選択す ることで説明できるかを議論する。Liu ${ }^{11)}$ は安定相間の 境界はFig.4に示すように脱酸平衡定数の組合せによって 移動することを指摘している。この罒は脱酸平衡定数 $K_{\mathrm{MgO}}$ として低い值を採用すると $\mathrm{MgO} / \mathrm{MgO} \cdot \mathrm{Al}_{2} \mathrm{O}_{3}$ 境界および $\mathrm{MgO} \cdot \mathrm{Al}_{2} \mathrm{O}_{3} / \mathrm{Al}_{2} \mathrm{O}_{3}$ 境界のどちらも低マグネシウム濃度側に 移動することを示している。実際，Table 2でリスト化した 平衡定数 $K_{\mathrm{MgO}}$ の值は互いに大きく異なっている。同様に,

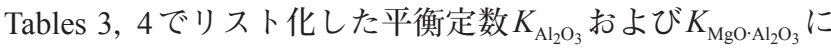
よって相境界は移動してしまう。しかし，どのような選択 をしても相境界はほぼ平行移動するだけなので，計算した 境界線の両側に実験值が存在することを説明するのは困難 である。

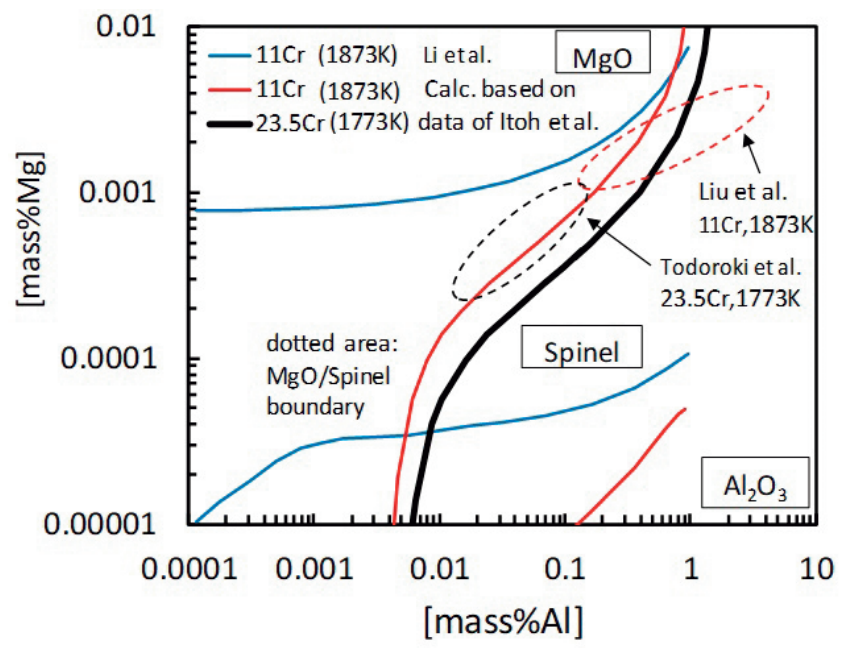

Fig. 3. Phase stability diagram of $\mathrm{MgO}, \mathrm{MgO} \cdot \mathrm{Al}_{2} \mathrm{O}_{3}$ and $\mathrm{Al}_{2} \mathrm{O}_{3}$ at $1873 \mathrm{~K}$. (Online version in color.)
Table 2. Equilibrium constants of $\mathrm{Mg}-\mathrm{O}$ system in liquid iron at $1873 \mathrm{~K}$.

\begin{tabular}{cccc}
\hline year & $\operatorname{logK}$ & Author & Ref.No. \\
\hline 1974 & -7.86 & G.K.Sigworth et al. & 27 \\
1974 & -5.5 & V.I.Yavoiskii et al. & 28 \\
1977 & -5.12 & E.B.Teplitskii et al. & 29 \\
1980 & -9.24 & A.P.Gorobetz & 30 \\
1985 & -8.54 & I.S.Kulikov & 31 \\
1986 & -5.7 & M.Nadif et al. & 32 \\
1991 & -7.74 & E.T.Turkdogan & 33 \\
1994 & -7.8 & R.Inoue et al. & 34 \\
1997 & -7.86 & H.Ohta et al. & 35 \\
1997 & -6.03 & Q.Han et al. & 36 \\
1997 & -6.8 & H.Itoh et al. & 16 \\
2000 & -7.21 & J.D.Seo et al. & 37 \\
2003 & -7.24 & W.G.Seo et al. & 38 \\
2009 & -7.59 & N.Satoh et al. & 39 \\
2011 & -8.07 & J.Gran et al. & 40 \\
\hline
\end{tabular}

Table 3. Equilibrium constants of Al-O system in liquid iron at $1873 \mathrm{~K}$.

\begin{tabular}{cccc}
\hline year & $\operatorname{logK}$ & Author & Ref.No. \\
\hline 1974 & -13.34 & G.K.Sigworth et al. & 27 \\
1980 & -13.6 & S.Gustafsson et al. & 41 \\
1988 & -13.6 & $\begin{array}{c}\text { Steelmaking Data } \\
\text { Sourcebook (JSPS) }\end{array}$ & 19 \\
1994 & -13.35 & H.Suito et al. & 42 \\
1994 & -13.3 & S.W.Cho et al. & 43 \\
1995 & -14.01 & S.Dimitrov et al. & 44 \\
1997 & -12.57 & H.Itoh et al. & 17 \\
1998 & -12.99 & J.D.Seo et al. & 45 \\
2009 & -12.84 & N.Satoh et al. & 39 \\
2003 & -13.34 & H.Ohta et al. & 21 \\
\hline
\end{tabular}

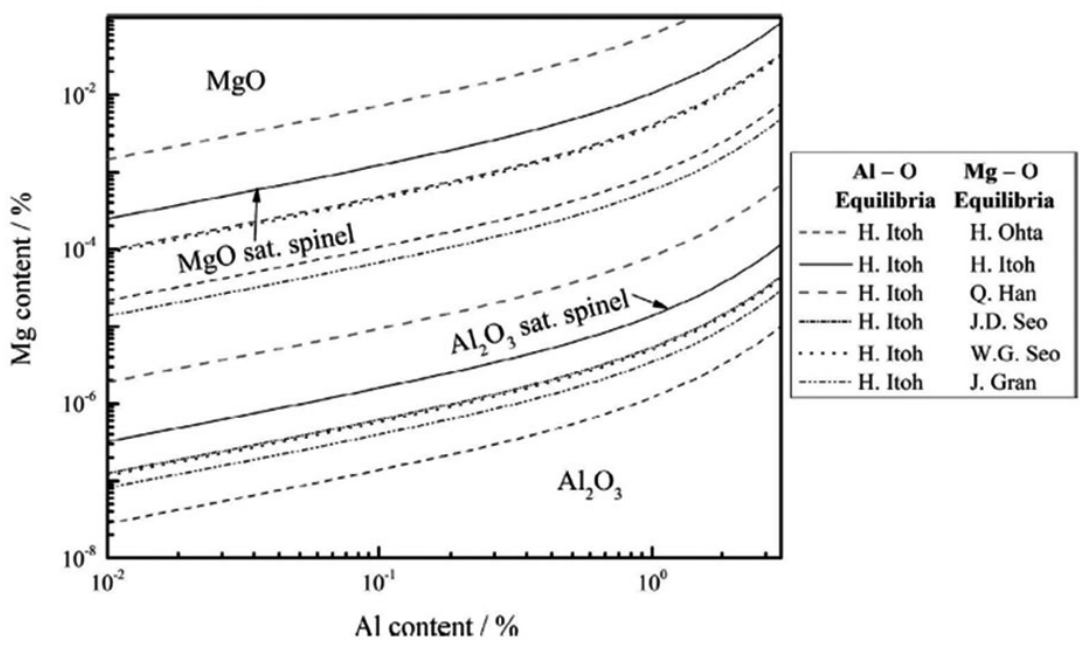

Fig. 4. Calculated $\mathrm{MgO} /$ spinel $/ \mathrm{Al}_{2} \mathrm{O}_{3}$ phase stability diagram at $1873 \mathrm{~K}^{11)}$. 


\section{$2 \cdot 3$ スラグ巻きこみ起源の介在物}

ここまで, 介在物は脱酸反応によって生成すると仮定し て議論を進めてきた。しかし，溶鋼中のスピネル介在物の 一部はスラグ巻きこみによってもたらされたものである と主張する研究者もいる。Hojo ら ${ }^{48)}$ はステンレス鋼を生 産する工場でAODから取鍋への出鋼時，あるいは，タン ディッシュで炭酸ストロンチウムをトレーサーとして添加 し，Fig.5に示すように介在物生成の起源を調査している。 その結果, 精錬工程から鋳造工程への過程で溶鋼中の温度 が低下し，懸濁した $\mathrm{AOD}$ スラグ粒に $\mathrm{MgO}-\mathrm{Al}_{2} \mathrm{O}_{3}$ スピネル が晶出することを熱力学計算を通じて見出した。同様の 知見は他の研究者らによっても発表されている ${ }^{49-52)}$ 。Kim ら ${ }^{49)}$ はFig.6のように介在物組成が変化すること示した。 Ehara ${ }^{51,52)}$ は介在物のアルミナ濃度変化が温度低下を考 慮した計算結果とほぼ一致することをFig.7で示した。し かし，どちらの值も十分良い一致を示したとはいえない。 脱酸平衡定数 $K_{\mathrm{Al}_{2} \mathrm{O}_{3}}$ はこれまでに多数の研究者ら ${ }^{17,19,27,39,45)}$ によってそれぞれ異なる值が報告されており，この脱酸 平衡定数 $K_{\mathrm{Al}_{2} \mathrm{O}_{3}}$ の選択が影響していた可能性がある。Fig. 8 は $\log K_{\mathrm{Al}_{2} \mathrm{O}_{3}}$ と温度の逆数の関係を示したものである。この 図から，ばらつき幅が 1873 Kで1.0 (-13.6から-12.6), $1773 \mathrm{~K}$ で1.6（-15.5から-13.9）であることがわかる。換 言すれば, 低温で平衡定数のばらつきが大きくなることを 意味している。1773 K という低温は溶鉄の融点よりも低 く，そのために研究例が少ない可能性がある。

\section{$2 \cdot 4$ 介在物組成に及ぼすカルシウム濃度の影響}

多くの研究者が有害なスピネル介在物の作用を緩和す るためにカルシウムの利用を提案している ${ }^{53)}$ 。溶鋼中のカ

Table 4. Equilibrium constants of $\mathrm{MgO} \cdot \mathrm{Al}_{2} \mathrm{O}_{3}=\mathrm{MgO}+\mathrm{Al}_{2} \mathrm{O}_{3}$ at $1873 \mathrm{~K}$.

\begin{tabular}{cccc}
\hline year & $\operatorname{logK}$ & Author & Ref.No. \\
\hline 1965 & -0.84 & H.R.Rein et al. & 46 \\
1991 & -1.18 & O.Knacke et al. & 47 \\
2000 & -1.4 & K.Fujii et al. & 18 \\
\hline
\end{tabular}

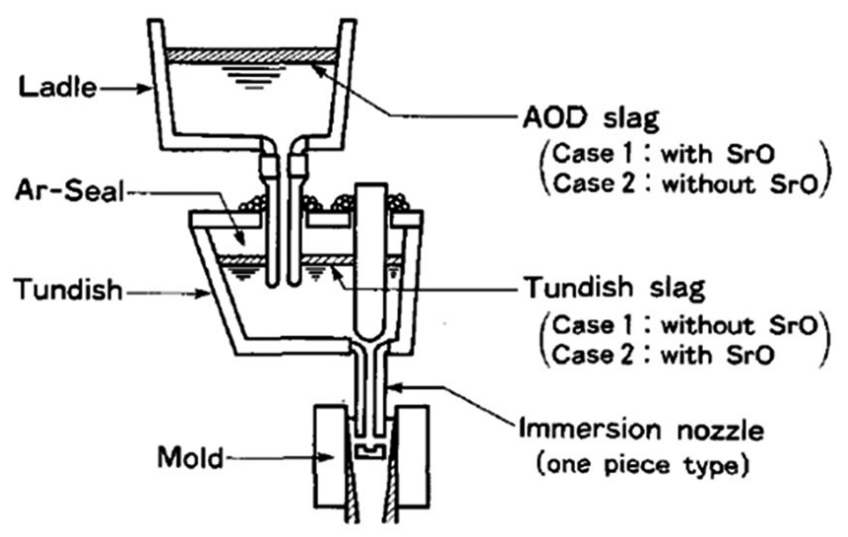

Fig. 5. Experimental conditions ${ }^{48)}$.
ルシウムは液体酸化物を形成し, $\mathrm{MgO} \cdot \mathrm{Al}_{2} \mathrm{O}_{3}$ スピネル介在 物を $\mathrm{MgO}-\mathrm{Al}_{2} \mathrm{O}_{3}-\mathrm{CaO}$ 系介在物に変える。Yang ${ }^{54)}$ はItoh $ら^{15)}$ と同じ手法を用いて熱力学計算を行い, クロムを含ま ない低炭素アルミキルド鋼中の介在物の相安定図に及ぼす カルシウム处理の影響を Fig.9のように評価している。こ の図は $\mathrm{MgO}$ と $\mathrm{Al}_{2} \mathrm{O}_{3}$ に挟まれた $\mathrm{MgO} \cdot \mathrm{Al}_{2} \mathrm{O}_{3}$ 領域の幅は変化 せず，液相酸化物である $12 \mathrm{CaO} \cdot 7 \mathrm{Al}_{2} \mathrm{O}_{3}$ がスピネル領域と 置き換わって領域を広げていることを示している。その一 方で, Li ${ }^{13,14)}$ は 11 mass\% \%ロム鋼と 18 mass\%クロム鋼 の相安定図を熱化学ソフトウェアで計算している。Fig.10 に示される計算結果は, カルシウム濃度の増加とともに $\mathrm{MgO}$ と $\mathrm{Al}_{2} \mathrm{O}_{3}$ に挟まれた $\mathrm{MgO} \cdot \mathrm{Al}_{2} \mathrm{O}_{3}$ 領域の幅は狭くなって おり, Yang ${ }^{54)}$ の結果とは一致しない。カルシウム濃度が $\mathrm{MgO} \cdot \mathrm{Al}_{2} \mathrm{O}_{3}$ 領域の縮小挙動に及ぼす影響が鋼中クロムの存 在で変化する理由は明らかではない。ここまで述べたこと から, $\mathrm{MgO}-\mathrm{Al}_{2} \mathrm{O}_{3}-\mathrm{CaO}$ 系の相安定図を理解し介在物組成を 制御するためには高クロム鋼の平衡定数ならびに相互作用 係数を含む熱力学データの再評価が必要である。

\section{3. $\mathrm{TiO}_{\mathrm{x}}-\mathrm{Al}_{2} \mathrm{O}_{3}-\mathrm{MgO}$ 系介在物}

\section{$3 \cdot 1 \quad \mathrm{TiO}_{\mathrm{x}}-\mathrm{Al}_{2} \mathrm{O}_{3}$ 系介在物の相安定図}

Kang and Lee ${ }^{55)}$ およびLi ら ${ }^{13,14)}$ はそれぞれ熱化学ソフト ウェアを利用して Ti含有アルミキルド鋼の研究を行って いる。報告された結果をFig.11に示す。この図はクロム濃 度の増加にともない相境界がわずかに低マグネシウム濃度 側へ移動することを示している。しかし, Fe-Al-Ti-O系の

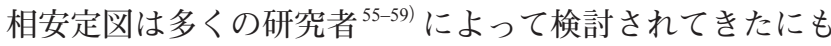
関わらず，クロムを含まない溶鉄条件でさえ意見が分かれ

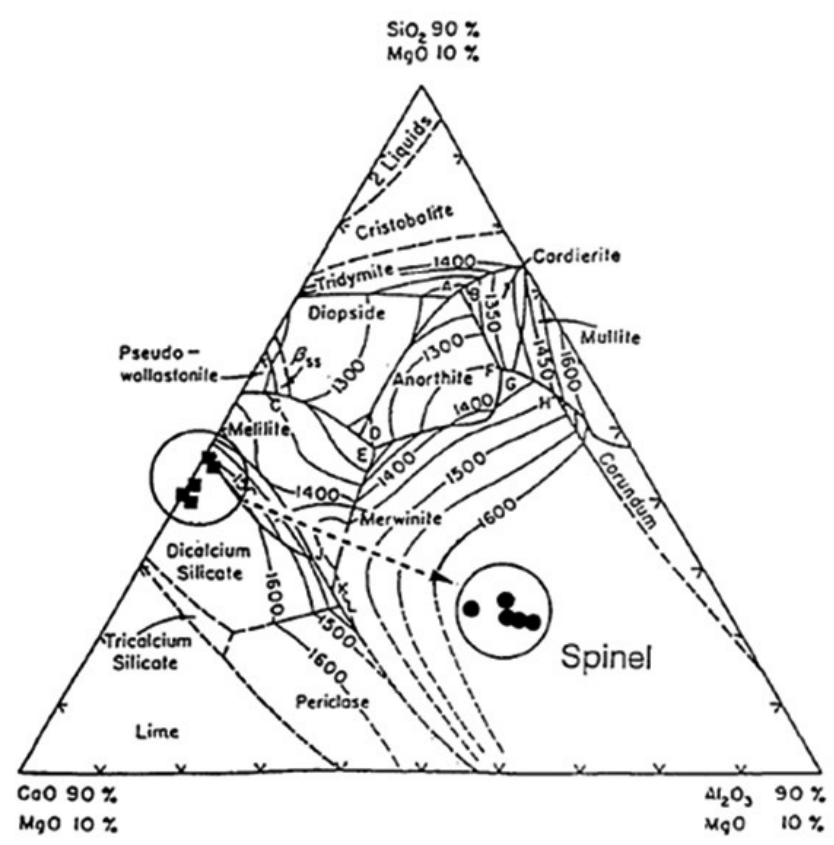

Fig. 6. Composition of inclusions (SUS304) ${ }^{49}$. 
ている。Ruby-Meyer ら ${ }^{56)}$ は相安定図を熱化学ソフトウェ アで計算し, $1793 \mathrm{~K}$ では $\mathrm{Ti}_{2} \mathrm{O}_{3}$ 領域と $\mathrm{Al}_{2} \mathrm{O}_{3}$ 領域の間に液相 が存在することを示した。一方, 他の研究者ら ${ }^{55,57-59)}$ は [Al]

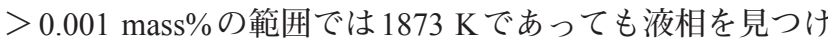
ることができていない。Ruby-Meyerらによるものを除いた
計算結果を Fig.12に示す。この図は報告值が互いに一致し ていないことを示している。したがって，溶鉄打よび高ク ロム鋼のいずれでも熱力学計算の結果が平衡実験で確認さ れることが強く期待される。

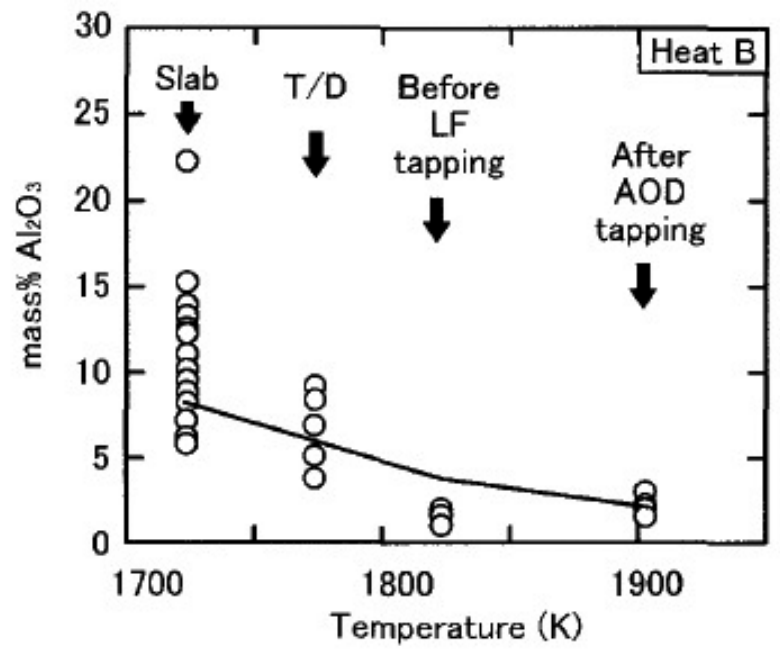

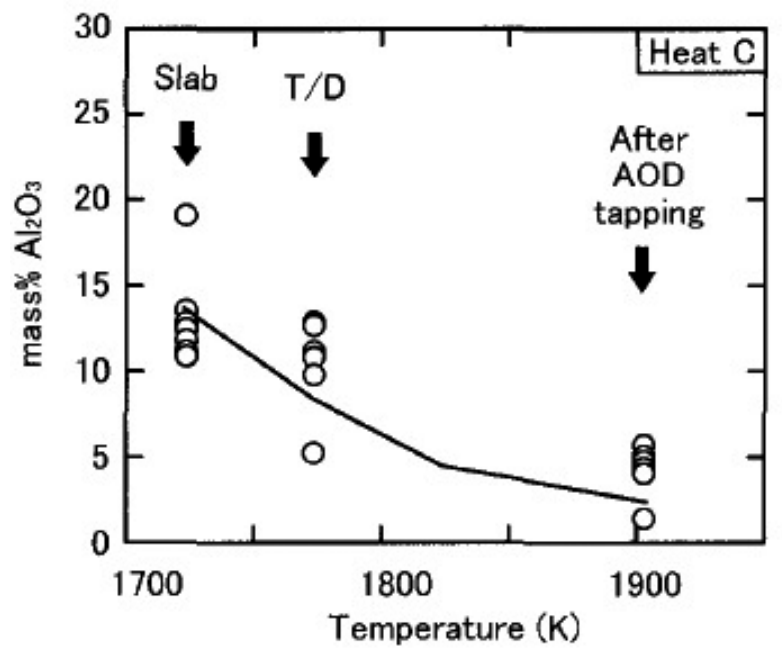

Analyzed $\quad \mathrm{O}$
Galculated

Fig. 7. Change of $\mathrm{Al}_{2} \mathrm{O}_{3}$ content in inclusions with temperature ${ }^{52)}$.

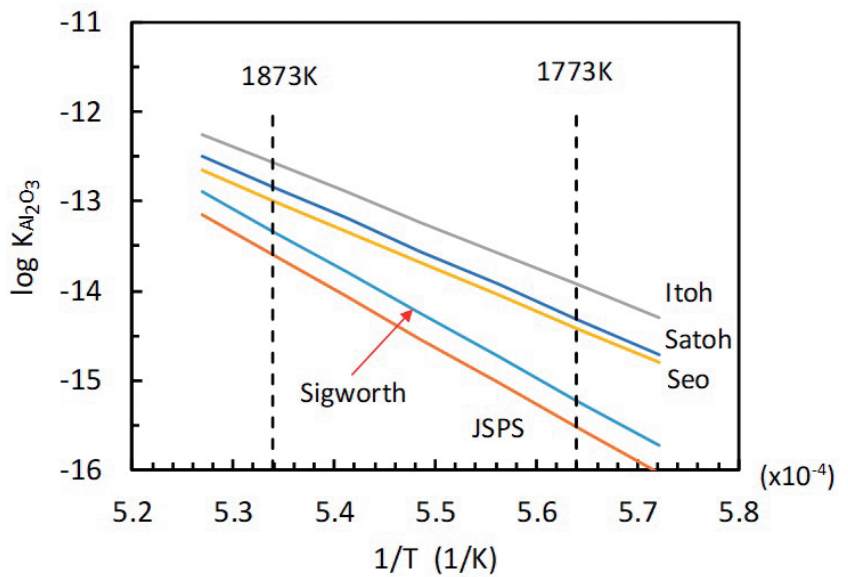

Fig. 8. Comparison of temperature dependence of $\log \mathrm{K}_{\mathrm{Al} 203}$ in liquid iron. (Online version in color.)

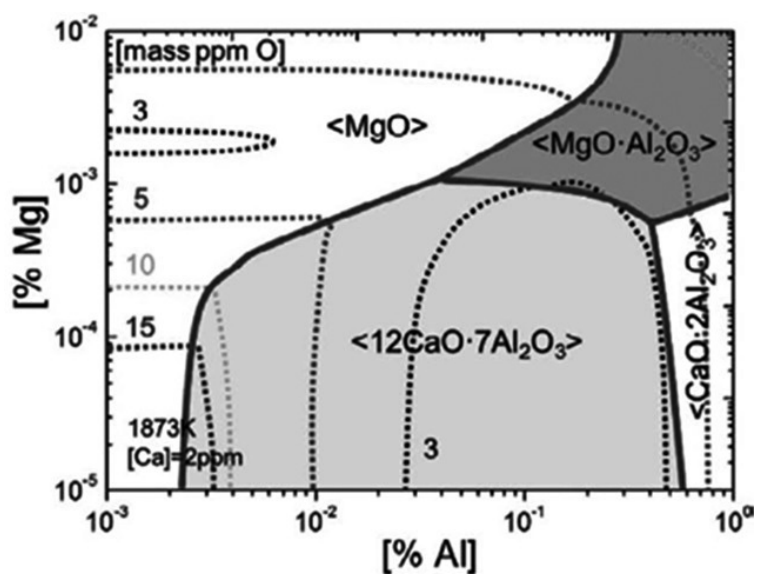

Fig. 9. Phase stability diagram of $\mathrm{MgO}, \mathrm{MgO} \cdot \mathrm{Al}_{2} \mathrm{O}_{3}$ and $\mathrm{CaO} \cdot 2 \mathrm{Al}_{2} \mathrm{O}_{3}$ inclusion formation in liquid iron at $1873 \mathrm{~K}$ $([\mathrm{Ca}]=2 \mathrm{ppm})^{54)}$. 


\section{$3 \cdot 2$ 介在物挙動に及ぼすスラグの影響}

$\mathrm{Kim}$ ら $^{49)}$ は $18 \mathrm{Cr}-8 \mathrm{Ni}$ ステンレス鋼製品中の $\mathrm{CaO}-\mathrm{SiO}_{2}-$ $\mathrm{Al}_{2} \mathrm{O}_{3}-\mathrm{MgO}-\mathrm{TiO}_{2}$ 系介在物を研究している。Fig.13に示す通

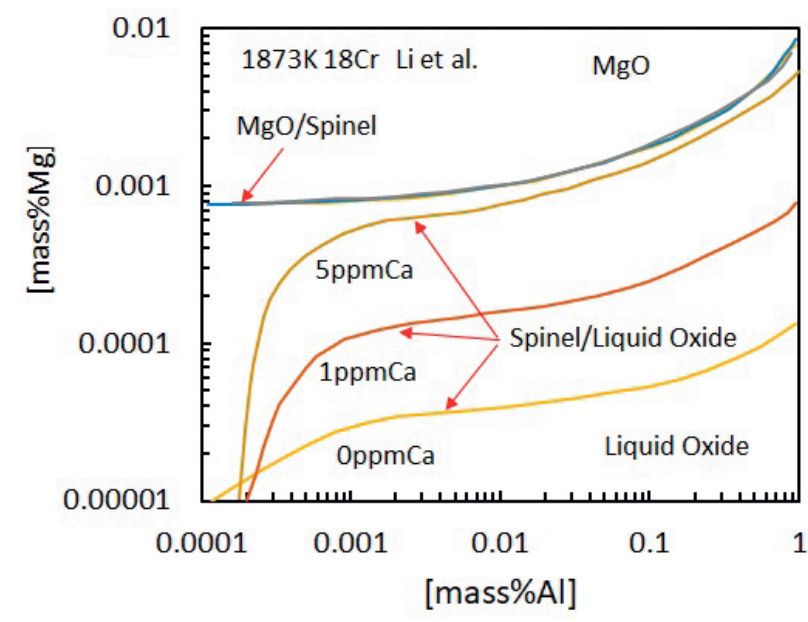

Fig. 10. Phase stability diagram of inclusion in $18 \% \mathrm{Cr}$ molten steel at $1873 \mathrm{~K}$. (Online version in color.)

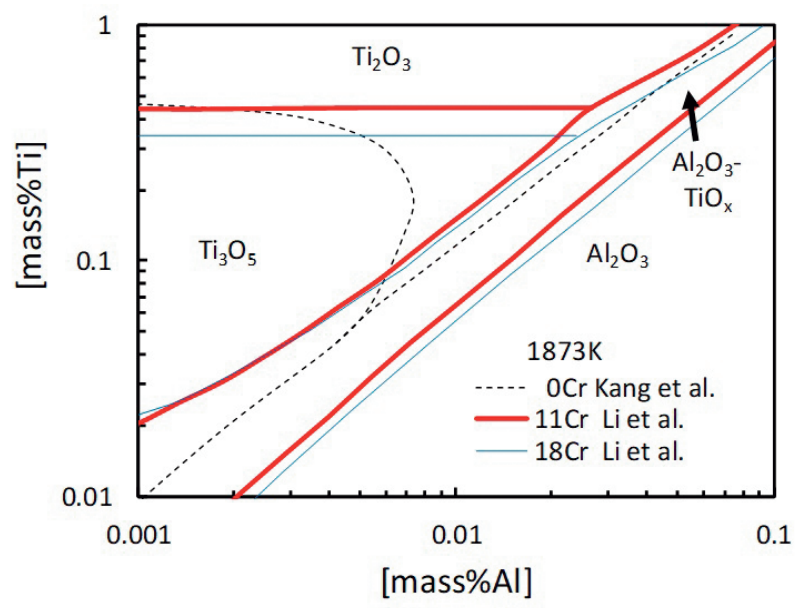

Fig. 11. Phase stability diagram of inclusion in $0 \%, 11 \%, 18 \% \mathrm{Cr}$ molten steel at $1873 \mathrm{~K}$. (Online version in color.)

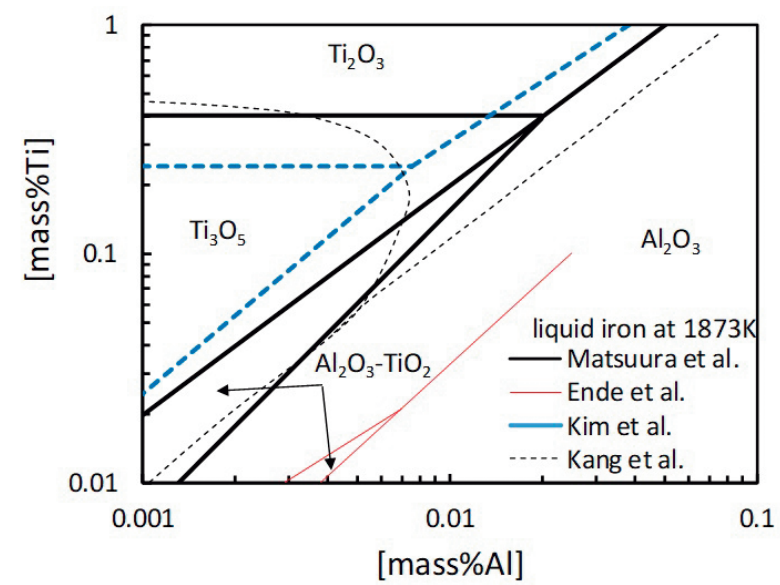

Fig. 12. Phase stability diagram of inclusion in liquid iron at $1873 \mathrm{~K}$. (Online version in color.)
り，スラグ起源の介在物はスラグから溶鋼に巻き込まれ， 一部は添加されたチタンによって脱酸され, AODから鋳 造までの温度降下によって介在物中の $\mathrm{TiO}_{2}$ の濃度が増加 することを見出した。その結果, Fig.14に示すように融点 の高い $\mathrm{MgO} \cdot \mathrm{Al}_{2} \mathrm{O}_{3}$ および $\mathrm{TiO}_{2}$ 介在物が晶出する。

熱化学ソフトゥェアを使った $\mathrm{TiO}_{\mathrm{x}}-\mathrm{MgO}-\mathrm{Al}_{2} \mathrm{O}_{3}$ 系の相安

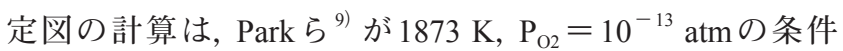
で, Li and Cheng ${ }^{60)}$ が $1873 \mathrm{~K}, \mathrm{P}_{\mathrm{O} 2}=10^{-12} \mathrm{~atm} の$ 条件でそれ ぞれ行っている。前者は塩基度の影響を評価し，塩基度の 增加にともない介在物が液相からスピネル十液相へ変化 すると報告している。後者はスラグ中 $\mathrm{CaF}_{2}$ 濃度の影響を調 査し, $\mathrm{CaF}_{2}$ 濃度の増加にともない介在物が $\mathrm{TiO}_{\mathrm{x}}-\mathrm{Al}_{2} \mathrm{O}_{3}(\mathrm{Sp})$ から $\mathrm{MgO}-\mathrm{Al}_{2} \mathrm{O}_{3}-\mathrm{TiO}_{\mathrm{x}}(\mathrm{TiSp})+$ liquidへ, 更に $\mathrm{MgO}+\mathrm{MgO}-$

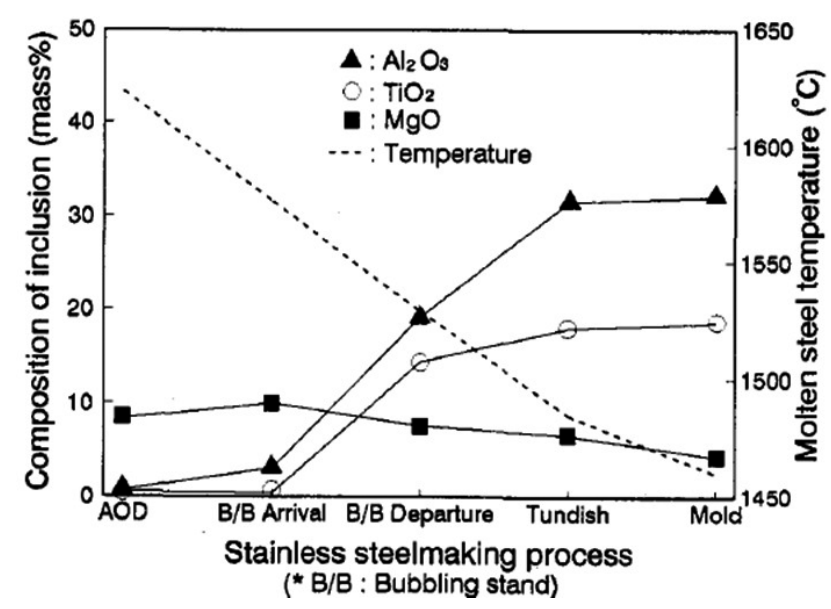

Fig. 13. Changes in composition of inclusions and molten steel temperatures at stainless steelmaking process ${ }^{49)}$.
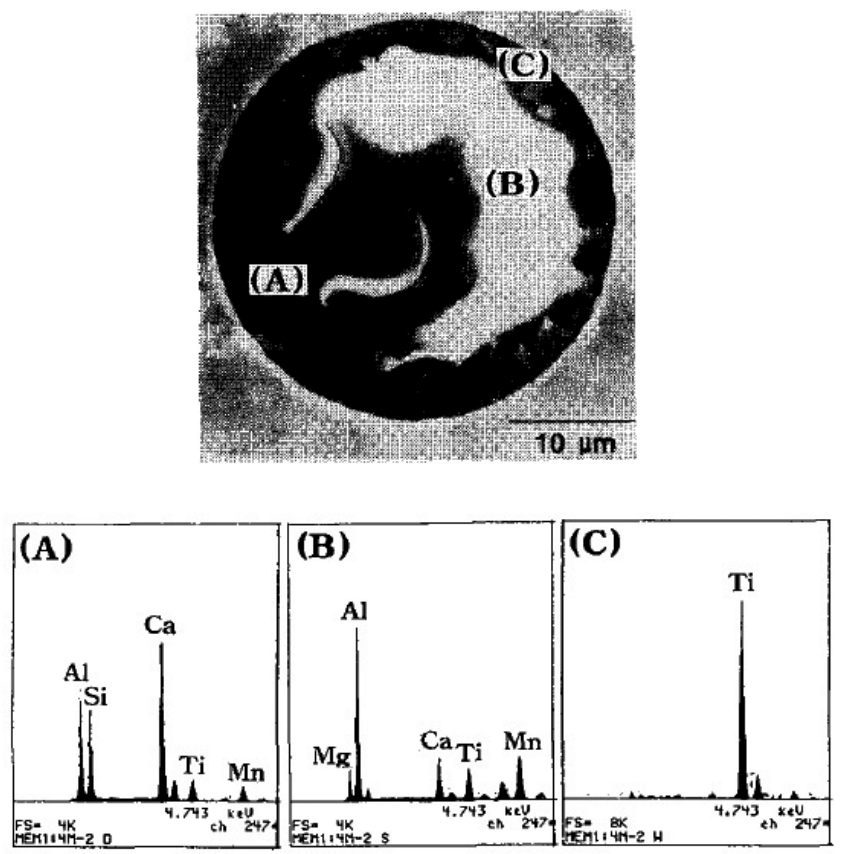

Fig. 14. SEM micrograph of a typical inclusion causing defects on coil surface and EDS of each phase ${ }^{49)}$. 


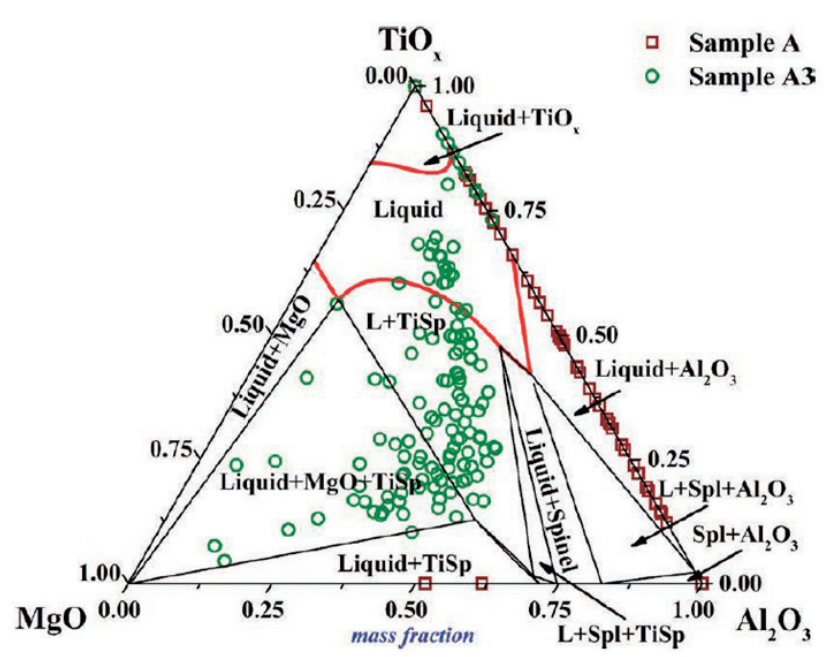

Fig. 15. Composition distributions of inclusions in $\mathrm{MgO}-\mathrm{Al}_{2} \mathrm{O}_{3}$ $\mathrm{TiO}_{\mathrm{x}}$ phase stability diagram $\left(1873 \mathrm{~K}, \mathrm{P}_{\mathrm{O} 2}=10^{-12} \mathrm{~atm}\right)$. ${\text { (Online version in color. }{ }^{60)}}^{60}$

$\mathrm{Al}_{2} \mathrm{O}_{3}-\mathrm{TiO}_{\mathrm{X}}(\mathrm{TiSp})+$ 液相へ変化することを Fig.15で示した。 な打，図中の Sample A はスラグ/メタル反応前のプリメル 卜状態, Sample A3は 10.07 mass $\% \mathrm{CaF}_{2}$ を含むスラグと反応 させた後のものである。Li and Cheng ${ }^{60)}$ は熱力学計算をも とに介在物中 $\mathrm{MgO}$ 濃度の増加は溶鋼中のマグネシウム濃 度に及ぼす $\mathrm{CaF}_{2}$ の影響で説明できるとしている。以上に示 したように，スラグの影響はスラグ巻きこみと微小成分の 制御の点で無視できないことがわかる。

\section{4. 熱力学評価}

Wagner $^{61)}$ の展開式は熱力学的関係を計算するために広 く利用されてきた。それに加えて, Darkenの二乗形式 ${ }^{62,63)}$ やRedlich-Kister 型多項式 ${ }^{64,65)}$ も提案されている。特に, 後 者は高合金鋼を対象とした計算で精力的に採用されてい $3^{8,39,66-68)}$ 。最近, 3次の相互作用パラメーターを考慮する ことにより Fe-Ni合金の脱酸平衡を高精度に予測できるこ とが明らかにされている ${ }^{69)}$ 。今後, Redlich-Kister型多項式 が様々な高合金鋼へ適用されることが期待される。

\section{5. 結言}

高クロム鋼の介在物組成を制御することは，連続鋳造時 の浸漬ノズル閉塞を防止し, 表面欠陥を含む鋼特性に及ぼ す介在物の悪影響を避けるために非常に重要である。し たがって，信頼性の高い熱力学データが必要である。しか し,クロム含有鋼の相安定図において $\mathrm{MgO}$ と $\mathrm{MgO} \cdot \mathrm{Al}_{2} \mathrm{O}_{3}$, $\mathrm{Al}_{2} \mathrm{O}_{3}$ の相境界は研究者により大きく異なっている。相互 作用パラメーターと脱酸平衡定数に基づく計算によれば, クロム含有鋼の相境界は低マグネシウム側に移動する。一 方, 熱化学ソフトゥェアからは全く異なる結果が出されて
いる。また, $1873 \mathrm{~K} よ り も$ 低温での脱酸平衡定数の温度依 存性に関する研究も介在物を制御する上で重要である。し かし, 低温での脱酸平衡定数は研究者間で大きく異なって いる。カルシウムは $\mathrm{MgO} \cdot \mathrm{Al}_{2} \mathrm{O}_{3}$ 介在物の悪影響を避けるた めに利用されてきたが，相安定図上で液相酸化物によって 置換される領域は低合金鋼と高クロム鋼とで異なった理解 がされている。

クロム含有鋼では $\mathrm{TiO}_{\mathrm{x}}-\mathrm{Al}_{2} \mathrm{O}_{3}-\mathrm{MgO}$ 系介在物の各酸化物 $\mathrm{Ti}_{2} \mathrm{O}_{3}, \mathrm{Ti}_{3} \mathrm{O}_{5}, \mathrm{Al}_{2} \mathrm{O}_{3}, \mathrm{TiO}_{\mathrm{x}}-\mathrm{Al}_{2} \mathrm{O}_{3}$ の間の相境界は全体的に低 チタン濃度側に移動することが熱化学ソフトウェアの計算 で示されている。しかし，計算された相安定図は溶鉄打よ び低合金鋼に打いてさえ研究者間で大きく異なっていると いう問題が存在する。さらに, スラグの塩基度や $\mathrm{CaF}_{2}$ 濃度 が $\mathrm{TiO}_{\mathrm{x}}-\mathrm{Al}_{2} \mathrm{O}_{3}-\mathrm{MgO}$ 系介在物の組成に強い影響を及ぼして いることが報告されているものの，炎の挙動は十分に明ら かにされていない。

以上のように, 信頼性の高い熱力学データの構築のた めには, 様々な条件での平衡実験が強く期待される。この 目的に対して, 新たな高精度の熱力学計算手法 (例えば, Redlich-Kister型多項式）も高クロム鋼を対象として利用さ れるべきである。

\section{謝辞}

本レビューは日本鉄鋼協会「スラグ・介在物制御による 高清浄度クロム鋼溶製」研究会グループの助言と援助を受 けて行われた。日本鉄鋼協会および本研究会に深く感謝申 し上げる。

\section{文献}

1) H.Todoroki and N.Shiga: Proc. 4th Int. Congr. on the Science and Technology of Steelmaking, ICS 2008, ISIJ, Tokyo, (2008), 121.

2 ) H.Todoroki and Y.Kobayashi: Proc. Asia Steel 2009 Int. Conf., (Busan), KIMM, Daejeon, (2009), CD-ROM.

3 ) K.Sakata: ISIJ Int., 46(2006), 1795. https://doi.org/10.2355/ isijinternational.46.1795

4 ) H.Todoroki, F.Kirihara, Y.Kanbe and Y.Miyazaki: Tetsu-toHagané, 100(2014), 539 (in Japanese). https://doi.org/10.2355/ tetsutohagane.100.539

5 ) H.Fujimura, S.Tsuge, Y.Komizo and T.Nishizawa: Tetsu-toHagané, 87(2001), 707 (in Japanese). https://doi.org/10.2355/ tetsutohagane1955.87.11_707

6 ) K.Kimura, S.Fukumoto, G.Shigesato and A.Takahashi: Tetsuto-Hagané, 98(2012), 601 (in Japanese). https://doi.org/10.2355/ tetsutohagane. 98.601

7 ) T.Koseki and H.Inoue: J. Jpn. Inst. Met., 65(2001), 644 (in Japanese). https://doi.org/10.2320/jinstmet1952.65.7_644

8 ) S.H.Seok, T.Miki and M.Hino: ISIJ Int., 49(2009), 1850. https://doi. org/10.2355/isijinternational.49.1850

9 ) J.H.Park, S.B.Lee and H.R.Gaye: Metall. Mater. Trans. B, 39(2008), 853. https://doi.org/10.1007/s11663-008-9172-4

10) J.H.Park and H.Todoroki: ISIJ Int., 50(2010), 1333. https://doi.org/ 10.2355/isijinternational.50.1333

11) C.Liu, X.Gao, S.Ueda, M.Guo and S.Kitamura: ISIJ Int., 60(2020), 1835. https://doi.org/10.2355/isijinternational.60.1835 
12) Z.Deng, Z.Liu, M.Zhu and L.Huo: ISIJ Int., 61(2021), 1. https://doi. org/10.2355/isijinternational.61.1

13) J.Li, G.Cheng, Q.Ruan, J.Li, J.Pan and X.Chen: ISIJ Int., 58(2018), 1042. https://doi.org/10.2355/isijinternational.58.1042

14) J.Li, G.Cheng, Q.Ruan, J.Pan and X.Chen: ISIJ Int., 58(2018), 2280. https://doi.org/10.2355/isijinternational.58.2280

15) H.Itoh, M.Hino and S.Ban-ya: Tetsu-to-Hagané, 84(1998), 85 (in Japanese). https://doi.org/10.2355/tetsutohagane1955.84.2_85

16) H.Itoh, M.Hino and S.Ban-ya: Tetsu-to-Hagané, 83(1997), 623 (in Japanese). https://doi.org/10.2355/tetsutohagane1955.83.10_623

17) H.Itoh, M.Hino and S.Ban-ya: Tetsu-to-Hagané, 83(1997), 773 (in Japanese). https://doi.org/10.2355/tetsutohagane1955.83.12_773

18) K.Fujii, T.Nagasaka and M.Hino: ISIJ Int., 40(2000), 1059. https:// doi.org/10.2355/isijinternational.40.1059

19) The Japan Society for the Promotion of Science, the 19th Committee on Steelmaking: Steelmaking Data Sourcebook, Gordon and Breach Science Publishers, New York, (1988), 50.

20) V.G.Mizin, Y.A.Agejev, A.Y.Zaslaysky, Y.A.Danilovich, S.A.Arehugov and N.A.Tulyn: Proc. 9th Japan-USSR Joint Symp. on Physical Chemistry of Metallurgical Processes, ISIJ, Tokyo, (1983), 92.

21) H.Ohta and H.Suito: ISIJ Int., 43(2003), 1301. https://doi.org/10. 2355/isijinternational.43.1301

22) Q.Han: Proc. 6th Int. Iron Steel Congress, Vol.1, ISIJ, Tokyo, (1990), 166.

23) T.Itoh, T.Nagasaka and M.Hino: ISIJ Int., 40(2000), 1051. https:// doi.org/10.2355/isijinternational.40.1051

24) M.Nadif and C.Gatellier: Process Technology, Proc. 5th Int. Iron and Steel Congr., ISS, Warrendale, PA, (1986), 741.

25) S.K.Jo, S.H.Kim and B.Song: Metall. Mater. Trans. B, 33(2002), 703. https://doi.org/10.1007/s11663-002-0023-4

26) C.Liu, X.Gao, S.Ueda and S.Kitamura: ISIJ Int., 59(2019), 268. https://doi.org/10.2355/isijinternational.59.268

27) G.K.Sigworth and J.F.Elliott: Met. Sci., 8(1974), 298. https://doi.org/ 10.1179/msc.1974.8.1.298

28) V.I.Yavoiskii, L.P.Volojimorov, V.P.Lujin, N.M.Kapitza and E.B.Teplitzkii: Izv. Akad. Nauk SSSR Met., 2(1974), 14 (in Russian).

29) E.B.Teplitskii and L.P.Valdimirov: Russ. J. Phys. Chem., 51(1977), 831.

30) A.P.Gorobetz: Metall. Koksokhim., 69(1980), 34.

31) I.S.Kulikov: Izv. Akad. Nauk Metall., 6(1985), 9.

32) M.Nadif and C.Gatellier: Rev. Metall., Cah. d'Inf. Tech., 83(1986), 377.

33) E.T.Turkdogan: Steel Res., 62(1991), 379. https://doi.org/10.1002/ srin. 199101314

34) R.Inoue and H.Suito: Metall. Mater. Trans. B, 25(1994), 235. https:// doi.org/10.1007/BF02665206

35) H.Ohta and H.Suito: Metall. Mater. Trans. B, 28(1997), 1131. https:// doi.org/10.1007/s11663-997-0069-4

36) Q.Han, D.Zhou and C.Xiang: Steel Res., 68(1997), 9. https://doi.org/ 10.1002/srin.199701770

37) J.D.Seo and S.H.Kim: Steel Res., 71(2000), 101. https://doi.org/10. 1002/srin.200005697

38) W.G.Seo, W.H.Han, J.S.Kim and J.J.Pak: ISIJ Int., 43(2003), 201. https://doi.org/10.2355/isijinternational.43.201

39) N.Satoh, T.Taniguchi, S.Mishima, T.Oka, T.Miki and M.Hino: Tetsu-to-Hagané, 95(2009), 827 (in Japanese). https://doi.org/10. 2355/tetsutohagane.95.827

40) J.Gran and D.Sichen: Metall. Mater. Trans. B, 42(2011), 921. https:// doi.org/10.1007/s11663-011-9557-7

41) S.Gustafsson and P.O.Mellberg: Scand. J. Metall., 9(1980), 111.

42) H.Ohta and H.Suito: The Final Report of Ultra Clean Steel Research
Group, Thermodynamics of Production of Ultra Clean Steel, ISIJ, Tokyo, (1999), 66

43) S.W.Cho and H.Suito: ISIJ Int., 34(1994), 177. https://doi.org/10. 2355/isijinternational.34.177

44) S.Dimitrov, A.Weyl and D.Janke: Steel Res., 66(1995), 3. https://doi. org/10.1002/srin.199501762

45) J.D.Seo, S.H.Kim and K.R.Lee: Steel Res., 69(1998), 49. https://doi. org/10.1002/srin.199801342

46) H.R.Rein and J.Chipman: Trans. Metall. Soc. AIME, 233(1965), 415.

47) O.Knacke, O.Kubaschewski and K.Hesselmann: Thermochemical Properties of Inorganic Substances, 2nd ed., Springer-Verlag, Berlin, (1991).

48) M.Hojo, R.Nakao, T.Umezaki, H.Kawai, S.Tanaka and S.Fukumoto: ISIJ Int., 36(1996), S128. https://doi.org/10.2355/isijinternational.36. Suppl_S128

49) J.W.Kim, S.K.Kim, D.S.Kim, Y.D.Lee and P.K.Yang: ISIJ Int., 36(1996), S140. https://doi.org/10.2355/isijinternational.36.Suppl S140

50) W.Y.Cha, D.S.Kim, Y.D.Lee and J.J.Pak: ISIJ Int., 44(2004), 1134. https://doi.org/10.2355/isijinternational.44.1134

51) Y.Ehara, S.Yokoyama and M.Kawakami: Tetsu-to-Hagané, 93(2007), 208 (in Japanese). https://doi.org/10.2355/tetsutohagane. 93.208

52) Y.Ehara, S.Yokoyama and M.Kawakami: Tetsu-to-Hagané, 93(2007), 475 (in Japanese). https://doi.org/10.2355/tetsutohagane. 93.475

53) B.Harkness and D.Dyson: Proc. METEC Congr. '94, (Düsseldorf), VDEh, Düsseldorf, (1994), 70.

54) W.Yang, L.Zhang, X.Wang, Y.Ren, X.Liu and Q.Shan: ISIJ Int., 53(2013), 1401. https://doi.org/10.2355/isijinternational.53.1401

55) Y.B.Kang and J.H.Lee: ISIJ Int., 57(2017), 1665. https://doi.org/10. 2355/isijinternational.ISIJINT-2017-182

56) F.Ruby-Meyer, J.Lehmann and H.Gaye: Scand. J. Metall., 29(2000), 206. https://doi.org/10.1034/j.1600-0692.2000.d01-24.x

57) H.Matsuura, C.Wang, G.Wen and S.Sridhar: ISIJ Int., 47(2007), 1265. https://doi.org/10.2355/isijinternational.47.1265

58) W.Y.Kim, J.O.Jo, C.O.Lee, D.S.Kim and J.J.Pak: ISIJ Int., 48(2008), 17. https://doi.org/10.2355/isijinternational.48.17

59) M.A.Van Ende, M.Guo, R.Dekkers, M.Burty, J.Van Dyck, P.T.Jones, B.Blanpain and P.Wollants: ISIJ Int., 49(2009), 1133. https://doi.org/ 10.2355/isijinternational.49.1133

60) J.Li and G.Cheng: ISIJ Int., 59(2019), 2013. https://doi.org/10.2355/ isijinternational.ISIJINT-2019-277

61) C.Wagner: Thermodynamics of Alloys, Addison-Wesley, Cambridge, MA, (1952), 47.

62) L.S.Darken: Trans. Metall. Soc. AIME, 239(1967), 80.

63) L.S.Darken: Trans. Metall. Soc. AIME, 239(1967), 90.

64) M.Hillert and L.-I.Staffansson: Acta Chem. Scand., 24(1970), 3618. https://doi.org/10.3891/ACTA.CHEM.SCAND.24-3618

$65)$ N.Saunders and A.P.Miodownik: Calphad (Calculation of Phase Diagrams), A Comprehensive Guide, Pergamon, Oxford, UK, (1998), 91.

66) T.Miki and M.Hino: ISIJ Int., 45(2005), 1848. https://doi.org/10. 2355/isijinternational.45.1848

67) R.Yamamoto, H.Fukaya, N.Satoh, T.Miki and M.Hino: ISIJ Int., 51(2011), 895. https://doi.org/10.2355/isijinternational.51.895

68) Y.Bi, A.V.Karasev and P.G.Jönsson: ISIJ Int., 53(2013), 2099. https://doi.org/10.2355/isijinternational.53.2099

69) H.Fukaya, S.Suzuki, K.Kajikawa, B.Blanpain, M.Guo and A.Malfliet: JSW Tech. Rev., 69(2018), 9. 